NBER WORKING PAPER SERIES

\title{
INTERRACIAL FRIENDSHIPS IN COLLEGE
}

\author{
Braz Camargo \\ Ralph Stinebrickner \\ Todd R. Stinebrickner \\ Working Paper 15970 \\ http://www.nber.org/papers/w15970
}

\section{NATIONAL BUREAU OF ECONOMIC RESEARCH \\ 1050 Massachusetts Avenue \\ Cambridge, MA 02138}

May 2010

We would like to thank Peter Arcidiacono, John Bound, Kerwin Charles, Stacy Dickert--Conlin, Lance Lochner, Eugenia Toma, and numerous seminar participants for very useful comments and suggestions. This paper would not have been possible without the help of Dianne Stinebrickner and the tireless efforts of Lori Scafidi. We are extremely grateful for generous support from The Mellon Foundation, The Spencer Foundation, The University of Kentucky Center for Poverty Research, The National Science Foundation, The Social Sciences and Humanities Research Council of Canada, and Berea College. The views expressed herein are those of the authors and do not necessarily reflect the views of the National Bureau of Economic Research.

NBER working papers are circulated for discussion and comment purposes. They have not been peerreviewed or been subject to the review by the NBER Board of Directors that accompanies official NBER publications.

(C) 2010 by Braz Camargo, Ralph Stinebrickner, and Todd R. Stinebrickner. All rights reserved. Short sections of text, not to exceed two paragraphs, may be quoted without explicit permission provided that full credit, including (C) notice, is given to the source. 
Interracial Friendships in College

Braz Camargo, Ralph Stinebrickner, and Todd R. Stinebrickner

NBER Working Paper No. 15970

May 2010

JEL No. I0

\begin{abstract}
$\underline{\text { ABSTRACT }}$
Motivated by the reality that the benefits of diversity on a college campus will be mitigated if interracial interactions are scarce or superficial, previous work has strived to document the amount of interracial friendship interaction and to examine whether policy can influence this amount. In this paper we take advantage of unique longitudinal data from the Berea Panel Study to build on this previous literature by providing direct evidence about the amount of interracial friendships at different stages of college and by providing new evidence about some of the possible underlying reasons for the observed patterns of interaction. We find that, while much sorting exists at all stages of college, black and white students are, in reality, very compatible as friends; randomly assigned roommates of different races are as likely to become friends as randomly assigned roommates of the same race. Further, we find that, in the long-run, white students who are randomly assigned black roommates have a significantly larger proportion of black friends than white students who are randomly assigned white roommates, even when the randomly assigned roommates are not included in the calculation of the proportions. This last result contradicts previous findings in the literature.
\end{abstract}

\section{Braz Camargo}

Sao Paulo School of Economics University of Western Ontario bcamargo@uwo.ca

Ralph Stinebrickner Berea College ralph_stinebrickner@berea.edu
Todd R. Stinebrickner

Department of Economics

University of Western Ontario

London, Ontario, N6A 5C2

CANADA

and NBER

trstineb@uwo.ca 


\section{Introduction}

Motivated by the reality that the benefits of diversity on a college campus will be mitigated if interracial interactions are scarce or superficial, previous work has strived to document the amount of interracial friendship interaction and to examine whether policy can influence this amount. In this paper we take advantage of unique longitudinal data to build on this previous literature by providing direct evidence about the amount of interracial friendship interaction at different stages of college and by providing new evidence about some of the possible underlying reasons for the observed patterns of interaction.

We begin in Section 2 with a description of our data, which come from the Berea Panel Study (BPS) conducted at Berea College. Berea College is located in central Kentucky and operates under a mission of providing educational opportunities to students of "great promise but limited economic resources."

In Section 3 we describe the basic empirical difficulty that is present if one wishes to characterize the amount of racial sorting in friendships - that friendship decisions are not observed directly in higher education data sources. Other existing approaches for characterizing the amount of sorting involve the use of indirect measures that permit the construction of only a single cross-section. In contrast, our survey efforts allow us to directly observe friendships at multiple times during school, starting at the end of the short orientation period that occurs immediately before the start of classes. We document a very high degree of racial sorting at all stages of college.

In Section 4 we examine what we can add to the existing literature by using our direct measures of friendship in conjunction with an experiment that arises because students at Berea are randomly (and unconditionally) assigned roommates in their freshman year. In terms of understanding why high degrees of racial sorting are observed, this experiment allows us to provide some of the first evidence about perhaps the most obvious potential explanation - that friendship compatibility is higher between students of the same race than between students of different races. This is possible since the experiment essentially forces some students to learn about their friendship compatibility with an individual of a different race while other students are forced to learn about their friendship compatibility with an 
individual of the same race. We find that roommates of different races are as likely to become friends as roommates of the same race.

Previous literature has emphasized the value of understanding whether a particular policy - in this case the random assignments of roommates - can influence the amount of interracial interaction later in school. In Section 4 we also find that, in the long-run, white students who are randomly assigned black roommates have a significantly larger proportion of black friends than white students who are randomly assigned white roommates, even when the randomly assigned roommates are not included in the calculation of the proportions. This contradicts the related finding in Boisjoly et al. (2006) who, without the benefit of direct measures of friendship, conclude that roommates "have little or no effect on harder to change behavior (such as befriending or socializing with someone from another racial/ethnic group)." ${ }^{1}$ As such, our results tend to strengthen the general message in Boisjoly et al. (2006) that roommates can matter in this context. However, the fact that the total amount of racial sorting remains roughly constant over time in the sample as a whole reveals the natural limit of this particular policy - that, by definition, only a limited number of white students can be matched with black roommates.

In Section 5 we examine what else can be learned from our data. In addition to the possibility that actual friendship compatibility may depend on whether two students are of the same race or not, there are two other possible explanations for why high degrees of racial sorting are observed. First, even if actual friendship compatibility does not depend on race, a person may incorrectly believe that he or she is less compatible with students of a different race. Second, the cost of meeting a potential friend, generally defined, or other costs of forming friendships may be higher if the potential friend is of a different race.

Given the evidence on actual interracial friendship compatibility from Section 4, ascertaining whether misperceptions about interracial friendship compatibility exist at a point in time requires knowledge of beliefs about interracial friendship compatibility at that point in time. The potential for learning about beliefs at the time of entrance comes from the fact

\footnotetext{
${ }^{1}$ Boisjoly et al. (2006) use survey questions asking whether "I have personal contact with people from other racial/ethnic groups", "I interact comfortably with people from other racial/ethnic groups", and "I socialize with someone with an African American Background." They find that the use of such questions do not produce a particularly clear or consistent picture.
} 
that we collected friendship decisions at a point in time -immediately before classes began in the students' freshman year-when all observed friends are new friends and institutional details at Berea suggest that the process by which a person encounters potential friends is, to a close approximation, unconditionally random. Nonetheless, even in this best case scenario, we stress in advance the difficulty of identifying beliefs from observed choices and pay careful attention to detailing the assumptions that would be necessary for identification in this case to be credible. As we also discuss in Section 5, identifying beliefs from observed choices becomes even more difficult at subsequent stages of college when not all observed friends are new friends and the process by which a student encounters potential friends is no longer random.

We finish in Section 6 with a discussion of how the conclusions of this work should be shaped by the reality that we are studying one particular school and of the limitations of using the roommate assignment process as a policy to influence interracial interactions.

\section{The Berea Panel Study}

The data come from the Berea Panel Study (BPS) which, as described in detail in Stinebrickner and Stinebrickner (2004, 2006, 2008a), was initiated by Todd Stinebrickner and Ralph Stinebrickner with the goal of understanding a variety of decisions that students make after entering college. The BPS consists of two cohorts that entered Berea in the fall of 2000 and 2001, respectively, and were surveyed between ten and twelve times each year while in school. Unique identifiers allow the survey data to be matched with student information from the school's administrative database.

Of particular importance for this paper, the BPS collected substantial information about friends and roommates at multiple times each year while students were in school. The baseline survey took place at the end of the mandatory orientation period, which we refer to as the "time of entrance" or the "start of classes." 2 One key difference between the two BPS cohorts is that friendship information was collected on the baseline survey only for the 2001

\footnotetext{
${ }^{2}$ In reality, the orientation period consists of two mandatory portions: a summer weekend and a short period immediately before the beginning of courses. This distinction has some significance in Section 4, and we discuss it in more detail there.
} 
cohort. Given this, we focus on the 2001 cohort for much of our work. For this cohort, the participation rate for the baseline survey was approximately .90, and Column 1 of Table 1 shows descriptive statistics for our sample from this cohort. Approximately $43 \%$ of students at Berea are male and $\mathbf{1 5 . 8 \%}$ of students are black. We note that, because the very large majority of non-black students are Caucasian, we combine all non-black students into a group that we refer to as "white" in the remainder of the paper.

The number of observations for which friendship information is observed at the time of entrance (354) is slightly smaller than the total number of baseline respondents (375) because two students indicated that they had no friends and nineteen students listed no friends that could be matched with individuals in our student database. The latter arises primarily because, at the time of our baseline survey, students had been at Berea for a short time and some individuals did not know both the first and last names of some of their friends. Nonetheless, students were reasonably knowledgeable about the names of their friends even at this early point in their college careers; we were able to find approximately $75 \%$ of the listed friends in our official database. ${ }^{3}$

Our survey collection efforts also allow us to directly identify friendships for students at the middle of the first, second, and third years. The total number of students for which friendship decisions are observed at these points are 335, 275, and 238, respectively. The decrease in sample size after the baseline is almost exclusively due to drop-outs - response rates were approximately 95\% after the baseline survey among individuals who were still enrolled at Berea and we were able to find approximately $95 \%$ of the listed friends after the baseline survey. We describe the sample construction in the Appendix. We note that attrition rates of black students are generally similar to those of white students, so that the proportion of black students at the school remains quite stable over time. We discuss the possible implications of survey attrition in Sections 3 and 4.

While the fact that the 2000 cohort did not answer the baseline survey makes its use problematic in some parts of the paper, this cohort is useful for examining certain issues in which having a larger sample size is of help. For the 2000 cohort, the total number of

\footnotetext{
${ }^{3}$ We find that $95 \%$ of friends were met at Berea. The results in the paper use all friends, but removing friends who were not met at Berea or removing students who have at least one friend who was not met at Berea leads to virtually no change in the results.
} 
observations for which friendships are observed in the middle of the first, second, and third years are 353,248 , and 233, respectively.

\section{Racial Sorting}

Non-trivial interactions between students of different races are necessary for diversity to yield benefits. Given this, one goal of recent literature has been to document the amount of sorting that is present in close friendships on a college campus. The empirical difficulty encountered in this exercise is that friendship decisions are not observed directly in higher education data sources. In response to this difficulty, other work has found creative, although typically indirect, measures of close friendships. For example, Marmaros and Sacerdote (2006) proxy for friendships using the quantity of email that is exchanged between pairs of students. Mayer and Puller (2008) obtain a more direct measure by examining friendship links from Facebook.com, although one might worry that these links capture both close friendships and acquaintances. ${ }^{4}$

The BPS includes very direct measures of friendship. At the end of the orientation period, immediately before classes began in the freshman year, we elicited friendship information for students in the 2001 cohort using the following survey question. ${ }^{5}$

Question A. Please list the names of the four people you currently consider your best friends at Berea College and provide information about where you met each of them. Please list in order with the person you would consider your best friend first.

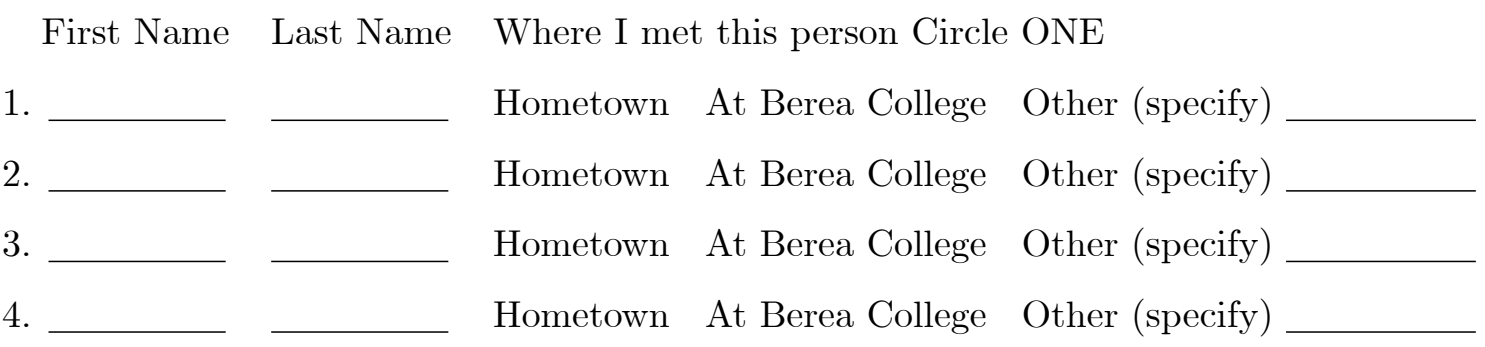

\footnotetext{
${ }^{4}$ As an extreme example, the thousands of Facebook friend requests that Michael Phelps received in the days after winning eight gold medals in the 2008 Summer Olympics undoubtedly came from people who did not know him personally.

${ }^{5}$ As a general note, it is never possible to know how answers to a particular survey question might be influenced by respondents' perceptions about how the question will be used. However, in this respect, it is worth noting that Question A, which does not refer to race in any way, was embedded in a very substantial survey with an obvious focus on academic performance and educational attainment.
} 
The relevant descriptive statistics in the first column of Table $2 \mathrm{~A}$ show that a very substantial amount of sorting by race is present at the start of classes when we characterize sorting using the person that is listed as the best friend in Question A. Pooling males and females and computing sample proportions, the Black (entrance) entry shows that $69.6 \%$ of black students in our sample have best friends who are black while the White (entrance) entry shows that only $5.7 \%$ of white students in our sample have best friends who are black. If sorting were purely random, then, in large samples, the proportion of black students who have black best friends would be $\mathbf{1 5 . 8 \%}$ and the proportion of white students who have black best friends would also be $15.8 \%$. Statistical tests overwhelmingly reject the former hypothesis, the latter hypothesis, and the hypothesis that the two conditions are jointly true. ${ }^{6,7}$ The first column of Table $2 \mathrm{~B}$ shows similar results at the start of classes when we characterize sorting using information about all individuals that are listed as friends in Question A. Pooling males and females we find that, on average (across sample members), $66.8 \%$ of the friends listed by a black student are black while only $9.7 \%$ of the friends listed by a white student are black.

The reality that other research on this topic has not been able to provide evidence about how sorting by race in friendships changes during school stems from the fact that the approaches used in these other papers for measuring friendships allowed only for the construction of a single cross-section. ${ }^{8}$ We provide direct information about how sorting

\footnotetext{
${ }^{6}$ The test of the null hypothesis that the proportion of black students who have black best friends is $15.8 \%$ has a standard normal test statistic of 11.334. The test of the null hypothesis that the proportion of white students who have black best friends is $15.8 \%$ has a standard normal test statistic of 4.778 . A test that the proportion of black students who have black best friends is the same as the proportion of white students who have black best friends has a standard normal test statistic of 12.030.

${ }^{7}$ Sixty percent of male black students in the sample have black best friends while $77 \%$ of female black students in the sample have black best friends. Given that this difference is not statistically significant at traditional levels, we do not pay specific attention to differences by sex in the remainder of the paper, although we do find statistically different sorting patterns by sex at some points after the first year.

${ }^{8}$ While, in theory, one could examine sorting across time by taking advantage of the fact that individuals at different stages of school are present in the single cross-section, in practice, this would not be very successful. For example, only $11 \%$ of freshmen and $23 \%$ of sophomores appear as "primary" sample members in the cross-section of Marmaros and Sacerdote (2006), with the implication being that roughly $80 \%$ of the email exchanged between two freshmen and roughly $60 \%$ of email exchanged between two sophomores would not be observed. In Mayer and Puller (2008), one would seemingly need to attempt to adjust for the reality that a students's Facebook friends at a point in time likely represent the cumulative set of friends that the person has met by that point in school (since people do not tend to remove friends from their Facebook pages). Regardless, providing this type of evidence is not the focus of either work.
} 
changes over time by taking advantage of the fact that we administered Question A not only at the time of entrance, but also in the middle of the first, second, and third years of college. Recall that the Black (entrance) and White (entrance) entries in the first column of Tables 2A (best friends) and 2B (all friends) show the amount of sorting at the time of entrance for the 2001 cohort. The remaining entries in the first column of Tables $2 \mathrm{~A}$ and 2B show the amount of sorting for the 2001 cohort in the middle of the first, second, and third years. The second column of Tables $2 \mathrm{~A}$ and $2 \mathrm{~B}$ show the amount of sorting for the 2001 cohort in the middle of the first, second, and third years using only observations for students who participated in all survey waves. The results from the first two columns of Tables $2 \mathrm{~A}$ and $2 \mathrm{~B}$ provide no evidence of decreased sorting over time, with the majority of the sample proportions moving in the direction of more sorting after the time of entrance. The first two columns of Tables 3A (best friends) and 3B (all friends) show similar results when we increase the sample size by combining both the 2000 and 2001 cohorts.

Sorting is also present on the basis of other characteristics. We focus on a student's high school grade point average (HSGPA), which is the strongest pre-college predictor of grade performance and drop-out at Berea. For illustration, examining friendship decisions in the middle of the first year for the combined 2000 and 2001 cohorts, the results from an OLS regression in the first column of Table 4 show that a student's HSGPA is an important predictor of the HSGPA of his best friend - the test of the null hypothesis that there exists no relationship has a t--statistic of 4.797 .

The second and third columns of Table 1 show that Berea has features which would be consistent with some form of affirmative action taking place in admissions. For example, the sample average HSGPA of white students is 3.43 while the sample average HSGPA of black students is 3.09. Then, it is natural to examine whether the difference in the amount of sorting on the basis of HSGPA is being driven to a large extent by the amount of sorting on the basis of race. The second column of Table 4 shows that adding a student's race to the regressions in the first column diminishes the strength of the relationship between a student's HSGPA and the HSGPA of his best friend, but that the effect of HSGPA remains significant at all conventional levels with a t-statistic of $3.354 .^{9}$

\footnotetext{
${ }^{9}$ Note also that there is no evidence of differences in the strength of sorting by race. The point estimates
} 
The fact that sorting is present on the basis of academic characteristics such as HSGPA suggests that the promotion of interracial interactions through affirmative action policies can be made harder by the reality that these policies lead to academic differences between black and white students at a school. ${ }^{10}$ However, because the sorting on the basis of academic characteristics such as HSGPA is relatively weak compared to sorting on the basis of race, we find that the influence of this mismatch here is, in practice, not particularly large. Specifically, combining the 2000 and 2001 cohorts, the first column of Table 5 examines the proportion of students who have a black best friend in the middle of the first year, but uses a linear probability model with whether a person's best friend is black as the dependent variable to control for HSGPA and a variety of other characteristics that could be correlated with race. The Black (year 1) and White (year 1) entries remain very similar to the corresponding entries in the first column of Table 3A. The second column of Table 5 examines the proportion of a student's friends who are black, but uses a regression model with the proportion of a student's friends that are black as the dependent variable, to control for the same set of characteristics. The Black (year 1) and White (year 1) entries remain very similar to the corresponding entries in the first column of Table $3 \mathrm{~B}^{11}$

\section{Evidence From a Roommate Experiment}

In this section we examine what can be learned about actual interracial friendship compatibility by using our direct measures of friendship in conjunction with an experiment which arises because students at Berea are assigned roommates in an entirely random fashion which, for example, does not take into account any characteristics or preferences of

associated with HSGPA are .152 and .143, respectively, when the first column of Table 4 is estimated using the friendships of only white students and only black students, respectively.

${ }^{10}$ For work that focuses on potential issues related to mismatch see, for example, Ayres and Brooks (2005), Rothstein and Yoon (2008), and Arcidiacono et al. (2010).

${ }^{11}$ Because of sample attrition, the composition of the sample changes over time. For example, in terms of academic quality, because HSGPA is related to drop-out, the average HSGPA for the sample tends to increase somewhat over time (e.g., from 3.37 at the start of classes to 3.45 in the middle of the second year). The finding in this section that the importance of sorting by HSGPA is relatively small compared to the importance of sorting by race is consistent with the result that the second column of Tables $2 \mathrm{~A}, 2 \mathrm{~B}$, 3A, and $3 \mathrm{~B}$ is similar to the first column of Tables $2 \mathrm{~A}, 2 \mathrm{~B}, 3 \mathrm{~A}$, and $3 \mathrm{~B}$, respectively. 
students. $^{12}$ We also investigate whether the roommate assignment process has an impact on interracial interactions.

\subsection{Evidence about Actual Interracial Compatibility}

Arguments about the benefits of educational diversity are often premised on the notion that students from different races have much in common. Furthermore, as pointed out in the Introduction, understanding whether black and white students are compatible as friends is important for understanding the reasons behind the sorting observed in the data. To the best of our knowledge, very little evidence exists about the issue of actual interracial compatibility.

Whether a student becomes friends with someone else in college depends on a variety of characteristics of that person, many of which are not easily observable when the two students initially encounter one another. In what follows, we adopt an informal definition of friendship compatibility that states that a student is as compatible with students of the same race as he is with students of a different race if he would be, on average, indifferent between students from the two races under a scenario in which: $(i)$ there exists no uncertainty about the friendship-relevant characteristics of all students; $(i i)$ there are no costs on friendships imposed by the views of others (e.g., stigma costs).

As pointed out above, a variety of characteristics that influence the quality of friendshipsense of humor and other personality traits, religious and political views, hobbies, interests, and past experiences, among others - are not apparent when two students first meet. As we discuss in detail in Section 5, this reality can create a disconnect between actual interracial friendship compatibility and observed friendship choices since, in the presence of uncertainty about actual interracial compatibility, beliefs about how compatibility is affected by race

\footnotetext{
${ }^{12}$ For those that need roommates, the assignment process is unconditionally random. A housing preference questionnaire is not used at Berea, due to a belief that such questionnaires are of limited use due to misreporting of behaviors such as smoking. Two weeks before the start of school (and after all members of the freshman class have been determined) pairs of roommates are drawn using a random number generator and each pair is randomly assigned to a room on a freshmen dorm floor. Thus, the process ensures randomness with respect to both one's roommate and the students in neighboring rooms. Stinebrickner and Stinebrickner (2004) provide indirect evidence of the randomness in the roommate assignment process by examining the correlation between several observable characteristics of students and their roommates. In addition, here we find no evidence of a relationship between a student's race and the race of his assigned roommate.
} 
may play an important role in decisions. The roommate experiment is valuable because, to the extent that sharing a room makes a non-trivial amount of interaction and observation unavoidable, the roommate assignment process implies that some students are forced to learn about their actual match quality with one randomly chosen roommate of the same race while other students are forced to learn about their actual match quality with one randomly chosen roommate of a different race. Then, seeing how roommates appear in friendship outcomes after the point at which learning has taken place reveals evidence about actual interracial friendship compatibility.

It seems reasonable to believe that much is learned about one's roommate after a couple of months of sharing a room, and we begin by examining friendship choices from our middleof-the-first-year survey which was collected in November. At this point, for the 2001 cohort 27 white students in our 2001 sample were randomly assigned black roommates and 155 white students were randomly assigned white roommates. ${ }^{13}$ The first column (2nd panel) of Table $6 \mathrm{~B}$ shows that, for this cohort, $44.4 \%$ of black roommates are listed as one of the four friends and $35.4 \%$ of white roommates are listed as one of the four friends. The first column (2nd panel) of Table $6 \mathrm{~A}$ shows that $18.5 \%$ of black roommates become best friends and $18.7 \%$ of white roommates become best friends. ${ }^{14}$

Combining the 2000 and 2001 cohorts to increase the number of observations, we have 60 white students who were identified as having been randomly assigned black roommates and 321 white students who were identified as having been randomly assigned white roommates. ${ }^{15}$

\footnotetext{
${ }^{13}$ The reality that, as described in Footnote 2, the orientation period actually consists of two portions is the primary reason that the number of observations in this section is smaller than that in Table $2-30 \%$ of students request a roommate that they have met in the first (summer) portion. Of the 298 white students in the first column of Table 2, 24 were assigned a single room, lived off-campus, or we could either not determine whom the student's roommate was or whether the student requested a roommate. Of the remaining 274 students, 193 were randomly assigned roommates ( 155 white, 27 black, 11 race missing-not used). Of the 56 black students in the first column of Table 2, 5 students were assigned a single room, lived off-campus, or we could either not determine whom the student's roommate was or whether the student requested a roommate. Of the remaining 51 students, 32 were randomly assigned roommates (28 white, 3 black, 1 race missing-not used). Students who choose roommates themselves during the first orientation period may be different than those that do not. However, in practice, we find that these students have very similar proportions as the entire sample. The proportions analogous to those in the first column of Table 2A are .718 and .086 for this group and the three tests described earlier in Footnote 6 continue to be overwhelmingly rejected with standard normal test statistics of 11.047, 4.314, and 8.715, respectively, when these students are removed.

${ }^{14}$ The standard errors associated with the proportions are $.095, .038, .074$, and .021 , respectively.

${ }^{15}$ With regard to sample sizes, it is worth mentioning that the sample in Boisjoly et al. (2006) has 1278 white students, only 35 of which were assigned at least one black roommate. Furthermore, when they
} 
The first column (1st panel) of Table $6 \mathrm{~B}$ shows that $35.0 \%$ of black roommates are listed as one of the four friends and $36.7 \%$ of white roommates are listed as one of the four friends. The first column (1st panel) of Table $6 \mathrm{~A}$ shows that $16.7 \%$ of black roommates become best friends and $16.5 \%$ of white roommates become best friends. ${ }^{16}$ Thus, because the sample proportions are always close for black and white roommates and are often higher for black roommates, we are never close to rejecting the null hypothesis that white students are equally compatible with black students as they are with white students. ${ }^{17}$ In other words, consistent with the notion that black and white students do have a lot in common, we find evidence in support of the notion that white students are, on average, as compatible with black students as they are with other white students.

Further, our results from the second and third years of college are also consistent with the conclusion that black and white students are compatible as friends. ${ }^{18}$ Column two of Table $6 \mathrm{~B}$ examines whether the original roommate was named as one of the four best friends in the middle of the second year. Column two of Table 6A examines whether the original roommate was named as the best friend in the middle of the second year. The results in column 2 of Tables $6 \mathrm{~A}$ and $6 \mathrm{~B}$ indicate that white students in the sample more often remained friends and best friends with their roommate in the second year if they were assigned a black roommate than if they were assigned a white roommate. For example, the second column (1st panel) of Table $6 \mathrm{~B}$ shows that $22.9 \%$ of black roommates in the combined cohorts are listed as one of the four friends in the middle of the second year and $13.3 \%$ of white roommates in the combined cohorts are listed as one of the four friends in the middle of the second year. ${ }^{19}$

investigate the effect of being assigned a black roommate on socialization with black students, their sample has 1087 white students, only 21 of which were assigned a black roommate.

${ }^{16}$ The standard errors associated with the proportions are $.061, .026, .020$, and .048 , respectively.

${ }^{17}$ One might be interested in confidence intervals (CI) associated with the difference between the sample proportion when the roommate is black and the sample proportion when the roommate is white. While negative values will be contained in the confidence intervals, the negative values are often not large relative to the proportion of roommates that are reported as friends. For example, the $90 \%$ CI for the difference in proportions (one of four friends) in the middle of the first year for the 2001 cohort is $(-.075, .254)$, so that even the lower bound is only $17 \%$ of the proportion of black roommates that are reported as friends (.444). Further, as will be discussed later, some $90 \%$ confidence intervals in later years do not even include zero.

${ }^{18}$ The validity of the experiment after the first year relies on the assumption that the race of the assigned roommate does not influence college drop-out decisions or survey participation decisions. This seems reasonable given that students are equally happy with black and white roommates.

${ }^{19}$ The $90 \%$ confidence interval for this difference, $(.003, .187)$, does not include zero, providing strong evidence of interracial compatibility. 
Similarly, the third column of Tables $6 \mathrm{~A}$ and $6 \mathrm{~B}$ reveal that white students in the sample more often remained friends and best friends with their roommate in the third year if they were assigned a black roommate than if they are assigned a white roommate.

Note that our experiment does not remove the external costs of interracial friendships (e.g., stigma costs), if they exist. In the next section we describe why we believe that these types of costs may not be important in our context. Regardless, it is worth noting that if such costs do exist, then they would strengthen our conclusion about actual interracial friendship compatibility since such costs would work against the formation of interracial friendships.

In the previous section we examined whether the promotion of interracial interactions through affirmative action policies could be made more difficult by the reality that these policies create a mismatch with respect to academic characteristics. Since the motivation for promoting interracial interactions is often that such interactions will allow students to learn that they have much in common with students from other races, it is valuable to understand the influence of academic mismatch on actual friendship compatibility.

We define the variable MISMATCH to be the absolute value of the difference between the HSGPA of a student and the HSGPA of the student's roommate. Combining the 2000 and 2001 cohorts and again limiting our sample to white students who were randomly assigned a roommate, the first column of Table 7 shows the results from regressing a dummy variable for whether the white student named his randomly assigned roommate as a friend in the middle of the first year on MISMATCH. We find that students are significantly less likely to become friends when their HSGPA's differ - the null hypothesis that MISMATCH has no effect on friendship is rejected at levels greater than $.015 .^{20}$

While the result in the above paragraph suggests that in general mismatch tends to decrease compatibility, it only strengthens the previous result that black and white students are very compatible; the (unconditional) likelihood that white students become friends with randomly assigned black roommates is as large as the likelihood that they become friends

\footnotetext{
${ }^{20} \mathrm{Re}$-estimating after stratifying on the basis of the race of the assigned roommate produces no evidence that the importance of MISMATCH varies with the race of the roommate. Among the white students assigned a white roommate the estimated effect (std. error) of MISMATCH is -.160(.072). Among the white students assigned assigned a black roommate the estimated effect of MISMATCH is -.141(.137). The average value of MISMATCH is .427 for roommates who become friends and .527 for roommates who do not become friends.
} 
with randomly assigned white roommates despite the fact that the randomly assigned black roommates are, on average, less compatible with the white students on the academic dimension. Formally, in the second column of Table 7 we add the race of the randomly assigned roommate to the regression in the first column. Holding the amount of mismatch constant, the estimated effect of having a black roommate is very close to zero, but slightly positive. ${ }^{21}$

It is not possible to directly provide evidence about the compatibility of black students with other black students since the random assignment implies that only a very small fraction of all matches would involve two black students. ${ }^{22}$ However, we can examine whether black students in the interracial pairs have views (about whether their roommates are friends) that are similar to those held by the white students in the interracial pairs. We have 28 black students in our initial sample who were identified as having been randomly assigned white roommates. ${ }^{23}$ In the first column (second panel) of Table $6 \mathrm{~B}$ we see that, for this cohort, $39.3 \%$ of these roommates are listed as one of the four friends (compared to $44.4 \%$ for white students in interracial pairs). In the first column (second panel) of Table 6A, we see that, for this cohort, $17.9 \%$ of these students become best friends (compared to $18.5 \%$ for white students in interracial pairs). ${ }^{24}$

Combining the 2000 and 2001 cohorts, we have 60 black students who were identified as having been randomly assigned white roommates. In the first column (first panel) of Table $6 \mathrm{~B}$, we find that $34.4 \%$ of these roommates are listed as one of the four friends (compared to $35.0 \%$ for white students in interracial pairs). In the first column (first panel) of Table 6A, we find that $18.0 \%$ of these students become best friends (compared to $16.7 \%$ for white students in interracial pairs). ${ }^{25}$ Thus, we find that black students in interracial pairs have views that are similar to the white students in these pairs. If the compatibility of black students with other black students is roughly the same as the compatibility of white students with other

\footnotetext{
${ }^{21}$ The "white assigned white" estimate is very close, but slightly larger, than the "white assigned black" estimate in the first column (first panel) of Table 6B.

${ }^{22}$ From Footnote 13 we see that $14.2 \%$ of the students who were randomly assigned roommates are black so that roughly $(.142)^{2}=.002$ of all matches would involve two black students. In the sample we find that .014 of all matches for which the race of the roommate can be identified involve two black students.

${ }^{23}$ The number of black students who have white roommates (28) does not have to be the same as the number of white students who have black roommates (27) because, in some cases, one of two roommates did not participate in the BPS.

${ }^{24}$ The standard errors associated with the proportions .393 and .179 are .092 and .072 , respectively.

${ }^{25}$ The standard errors associated with the proportions .344 and .180 are .062 and .048 , respectively.
} 
white students, then, by a simple transitivity argument, these results provide support to the notion that black students are as compatible with white students as they are with other black students.

One might wonder if, for some reason, the criteria used to name an assigned roommate as a friend are fundamentally different from the criteria used to name a non-roommate as a friend. Our findings related to academic mismatch provide evidence that general factors that one might expect to influence actual friendship compatibility can be found to be of

importance in our roommate experiment. Furthermore, this concern can be addressed directly by examining whether the initial roommate continued to be named as a friend after the first year when there is no longer a requirement for him to remain a roommate. We find no evidence that pairs of friends who are roommates in the first year are less likely to remain friends after the first year than pairs of friends who are not roommates in the first year. For example, combining cohorts, in the second year we observe 125 students who listed their initial, randomly assigned, roommate as a friend in the first year. Thirty-four percent of these students continue to name their initial roommate as a friend in the second year, whereas, for the sample as a whole, $31 \%$ of students who are listed as friends in the first year are also listed as friends in the second year. In the third year we observe 108 students who listed their initial, randomly assigned, roommate as a friend in the first year. Twenty-four percent of these students continue to name their initial roommate as a friend in the third year, whereas, for the sample as a whole, $18 \%$ of students who are listed as friends in the first year are also listed as friends in the third year.

\subsection{Can Policy Influence Interactions?}

The results of Section 3 indicate that, for the sample as a whole, there is significant racial sorting throughout college. This is important since a well-recognized condition necessary for affirmative action to be useful is that there is interaction between individuals of different races (Marmaros and Sacerdote (2006)). It is natural to wonder whether school policy can influence the amount of interaction. Indeed, providing evidence about this issue has been the primary objective of much of the literature in this area. 
The approach taken by Mayer and Puller (2008) to address this question is to specify a model which imposes significant structure on the meeting process. ${ }^{26}$ They calibrate the parameters of their model using their data from Facebook and use the estimates of the parameters characterizing students' preferences for friendships with individuals of different races to simulate the effect of counterfactual policies (e.g., changes to housing assignment rules or other changes that affect the likelihood that black and white students meet) on the amount of interracial friendships.

In the absence of an experiment, the approach of imposing structure in order to make progress on the question of whether policy can influence interactions seems reasonable. At the same time, assumptions about the meeting process and a variety of other assumptions that are needed for this approach to be viable are fundamentally unobservable, and it is not readily apparent how changes to the particular structure that is imposed would influence conclusions. For example, in order to achieve identification, Mayer and Puller (2008) assumes that preferences about people from different races do not change over time. But the motivation for affirmative action is that interaction is useful exactly because it might change preferences (through changes in beliefs).

We provide direct evidence about this issue by taking further advantage of the experiment involving randomly assigned roommates. Table 8A shows the proportion of a person's friends that are black in the middle of years one, two, and three, stratified by the race of the roommate that was randomly assigned for the freshman year. The proportions in the first panel include the roommate that was randomly assigned in the first year if this roommate is identified as a friend in the year being examined. The first column (first panel) shows that, on average, students have $16.5 \%$ black friends in the middle of the first year if they were randomly assigned a black roommate and $6.0 \%$ black friends in the middle of the first year if they were randomly assigned a white roommate. The null hypothesis that the average proportion of black friends in the middle of the first year does not depend on the race of the randomly assigned roommate is rejected at all traditional significance levels with the tstatistic having a value of -4.863 . The second and third columns (first panel) show similar

\footnotetext{
${ }^{26}$ The model of Mayer and Puller (2008) is based on Jackson and Rogers (2007). The latter, in work that does not focus on racial issues, examine a model of network formation in which an individual can form links (friendships) with other individuals either randomly or through his existing friends.
} 
results for the middle of the second and third years. Thus, the results indicate that policy can have a substantial effect on the amount of interracial interaction. Indeed, for white students assigned black roommates, the average proportion of black friends in the sample is greater than the proportion of black students (.158) at the school.

As shown in Subsection 4.1, many randomly assigned roommates end up being friends. This raises the question of whether the results in the first panel are being driven entirely by interactions with the assigned roommate. To examine this issue, the proportions in the second panel of Table 8A exclude the roommate that was randomly assigned in the freshman year if this roommate is identified as a friend in the year being examined. The results in the first column (second panel) show that, on average, white students have $8.1 \%$ black friends in the middle of the first year if they were randomly assigned a black roommate and $6.7 \%$ black friends in the middle of the first year if they were randomly assigned a white roommate. The null hypothesis that the average proportion of black friends in the middle of the first year does not depend on the race of the randomly assigned roommate cannot be rejected at any traditional significance levels since the t-statistic from the test has a value of - 656 . Thus, in the middle of the first year, the increased interracial interaction generated by the roommate assignment appears to be generated by the fact that roommates are often friends rather than by increases in the number of non-roommate friends that are black.

However, the results when roommates are excluded are different in the second and third years. For example, the results in the second column of Table 8A (second panel) show that, on average, white students in the sample have $15.9 \%$ black friends in the middle of the second year if they were randomly assigned a black roommate in the freshman year and $5.4 \%$ black friends in the middle of the second year if they were randomly assigned a white roommate. The null hypothesis that the average proportion of black friends in the middle of the second year does not depend on the race of the randomly assigned roommate in the freshman year is rejected at all traditional significance levels since the t-statistic from the test has a value of -4.341 . The third column of Table 5 (second panel) shows similar results in the middle 
of the third year. ${ }^{27,28}$

Thus, our results show that policy can have a substantial influence on interracial friendship interactions. Further, while the effect arises in the first year simply because students often become friends with their assigned roommate, the effect arises in subsequent years because students who are assigned black roommates are significantly more likely to choose other friends who are black. These results contradict the related findings in Boisjoly et al. (2006) which are obtained without the benefit of direct measures of friendship.

The two most obvious reasons for the effect after the first year are that either students' beliefs about interracial friendship compatibility change when they are assigned a black roommate in their freshman year or that network effects imply that students meet more potential friends who are black when they are assigned a black roommate in their first year. ${ }^{29}$ As discussed below in Subsection 5.2, distinguishing between these two possibilities is very difficult.

\section{Other Evidence}

In the previous section we used the roommate experiment to provide evidence that students of different races at Berea are compatible as friends and that policy can potentially influence the amount of interracial interaction of some students. In this section we examine what else can be learned from our data.

\footnotetext{
${ }^{27}$ One might wonder how survey attrition impacts the numbers in Table 8A. Our primary interest in Table $8 \mathrm{~A}$ is in examining whether, at certain points in time, there exist differences between white students who were assigned white roommates and white students who were assigned black roommates. In this case, one needs only to believe that attrition has similar effect on the two groups. This seems to be a reasonable assumption since the only difference between the groups at entrance is roommate race and there exists no evidence in Table $8 \mathrm{~A}$ that roommate race impacts attrition from the survey.

${ }^{28}$ While not our primary focus, changes in sample composition over time could potentially make it difficult to understand changes in Table $8 \mathrm{~A}$ that take place over time for a particular group. However, the results in Table 8B show very similar results to Table 8A when we examine only students who responded in all years.

${ }^{29}$ Other somewhat related possibilities are that black friends in the future are complements to existing black friends or that students with cross-race roommates acquire skills that make it easier for them to form future cross-race friendships.
} 


\subsection{Beliefs about Interracial Friendship Compatibility at the Start of Classes}

There are other factors besides interracial friendship compatibility that can also potentially influence friendship decisions, and thus explain the observed sorting by race. For a variety of reasons, it would be desirable to obtain evidence about the importance of these other factors. For example, arguments in support of affirmative action admission policies are often premised on the notion that students may have misperceptions about how much they have in common with individuals from other races (Alger (1997)). As such, even if actual friendship compatibility does not vary with the race of one's friend, it would be desirable to know whether students believe they are more compatible with students of the same race.

Here we ask what can be learned about a person's beliefs from his observed friendship choices. Roughly speaking, if the costs of meeting friends or other subsequent costs of friendships did not vary with the race of potential friends, then students' beliefs about interracial friendship compatibility would be identified directly from observed choices. The difficulty of ascertaining beliefs from observed choices arises because this assumption about costs is not generally plausible. To see why, consider the process by which a student meets potential friends. This meeting process, generally defined, involves two stages. First, during a particular period, a student "encounters" a variety of potential friends through his or her academic and non-academic activities. Second, given that many friendship-relevant characteristics may not be immediately observable during these encounters, a student must choose which of these potential friends he or she will spend some time with in order to learn more about friendship compatibility. It is not necessary to take a stand on how long this "evaluation" period lasts, but it includes, for example, "breaking the ice" in order to start a dialogue with a potential friend. We refer to the costs associated with these two stages as meeting costs.

The most commonly discussed reason why costs may vary with the race of potential friends is that, in general, students will be encountered in a non-random fashion in the first stage of the meeting process. Namely, a student may be involved in clubs, activities, social circles, or classes in which he encounters a disproportionate number of students of his own race. This concern led us to take advantage of the flexibility of our data collection efforts 
to document friendship decisions at the end of a period - the short orientation period which occurs before the freshman year - in which institutional details suggest that, to a reasonable approximation, randomness in encounters is a reasonable assumption.

Specifically, in terms of formal assignments made by the school, randomness is the appropriate way to characterize how students are assigned to their official orientation group, how students are assigned roommates and dormmates (Footnote 12), and how students are assigned to a job in Berea's mandatory work-study program (Stinebrickner and Stinebrickner (2003)). Randomness also seems to be a reasonable approximation for how students encounter potential friends through other social avenues during orientation. Indeed, particular clubs that might interest specific types of students do not begin activities during the orientation period and informal events (e.g., parties) held by upperclassmen (which might draw disproportionate numbers of particular types of students) are unlikely during this period since school rules imply that almost all students live on campus and upperclassmen are not present on campus during the orientation period. ${ }^{30}$ Instead, the primary social events would be general types of functions (e.g., cookouts, etc.) provided by the school that would presumably be of similar interest to all types of students.

Then, under the assumption that non-randomness in the encounter process is the sole reason that friendship costs vary with the race of potential friends, we can identify whether students believe they are more compatible with students of their own race by observing their friendship choices at the end of the orientation period (i.e., at the start of classes). The evidence from Section 3 of substantial sorting by race in friendship decisions at the start of classes suggests that, despite evidence from Section 4 that friendship compatibility does not depend on the race of the students, students believe that they are more compatible with students of the same race.

It is important to view the above conclusion with appropriate caution. In an effort to

\footnotetext{
${ }^{30}$ Contributing to the reality that it is very reasonable to assume that off-campus parties represent a negligible portion of social activities during the orientation period is the very low prevalence of alcohol use at Berea (Stinebrickner and Stinebrickner, 2008b). In some schools, one might worry that the assumption of randomness might be violated due to the presence of athletics. However, largely because a football team does not exist, the number of freshmen at Berea who would be on-campus for athletics before or during the orientation period is small. Further, using administrative data we find that athletes at Berea are not disproportionately of any particular race.
} 
allow the reader to draw his or her own conclusions, in the next two paragraphs we discuss possible reasons why non-randomness in the meeting process need not be the only reason why friendship costs may vary with the race of potential friends and discuss why the relevance of each reason might be somewhat mitigated in the friendship context.

In terms of the evaluation process, a first concern might be that students may feel it is costly to "break the ice" with someone of another race. However, such a feeling might be indicative of a belief that friendship compatibility varies with race given that starting a conversation is likely to be most difficult when two people do not have much in common to talk about. A second possibility, raised by Cornell and Welch (1996) in a labor market context, would be that students are worse at evaluating their friendship compatibility with a person of a different race, effectively making it costlier for them to form different-race friendships. However, from a conceptual standpoint, distinguishing between costs of this type and beliefs may make more sense in a labor market context than in the friendship context studied here. It seems likely that a belief that it is difficult to evaluate friendship compatibility with a student of a different race might arise from a feeling that there will not be much in common or that it will be difficult to communicate freely or comfortably. Then, if sorting is generated by this mechanism, it is perhaps indicative of a belief that friendship compatibility varies with race. A final possibility in the evaluation process is that both white and black students correctly believe that they are equally compatible with students of the other race, but at least one group believes that the other is biased. Thus, racial sorting would occur because students do not choose individuals of the other race for fear of this choice not being reciprocated. This is a somewhat different view of the data, but the conclusion for policy is essentially the same: there is some type of misperception.

Finally, a possible cost that does not fall under the heading of meeting costs would be that social norms (stigmas) imply that there is a cost to having both black friends and white friends. For example, if the same race friends of a student criticize him for having friends of a different race, then a person may not choose to have friends of both races even if he thinks that he is equally compatible with students of both races. However, there are a couple of things to note. First, if such a situation does exist, then it is strongly suggestive that at least some people on campus believe that blacks and whites are quite different and probably not 
particularly compatible - a view that is consistent with the notion that a misperception may exist. Second, unless one believes that roommates are able to be friends without appearing in public, this view of things seems inconsistent with the roommate findings from the previous section. Finally, stigmas of this type seem quite inconsistent with the environment at Berea, which is known for promoting interracial harmony. ${ }^{31}$

\subsection{Learning About Interracial Friendship Compatibility}

The evidence in the previous subsection raises the possibility that, while in reality students from different races are very compatible as friends, they may not realize this at the time of college entrance. An important policy question is whether the interracial interactions that occur on a campus are effective in correcting this possible misperception. To examine this question, one would need to ascertain beliefs about interracial friendship compatibility from observed choices at times subsequent to the start of classes. We begin by stressing the difficulty of this task, and then examine whether anything can be learned if we take advantage of the longitudinal nature of our data to operationalize assumptions that have been utilized recently in models of friendship formation.

Our examination in Subsection 5.1 of beliefs at the start of classes took advantage of two unique features of the orientation period: $(i)$ students were making all new friends during the orientation period; and $(i i)$ the process by which students encounter potential friends during the orientation period is to, a close approximation, unconditionally random. As we noted, even in this best case scenario, our results should be viewed cautiously since it is not possible to rule out the existence of costs of friendship formation that vary with the race of potential friends. At points of time subsequent to the start of classes, identifying beliefs from observed friendship choices becomes substantially more difficult since the two unique features described above no longer hold. If there is little turnover in friendships or if network effects are strong (so that new friends tend to be met through other friends), then sorting in earlier periods will tend to persist over time even if beliefs about interracial friendship

\footnotetext{
${ }^{31} \mathrm{~A}$ variant of this explanation would be that social stigmas are present because of the views of parents. For example, a student who believes that she is equally compatible with students of all races might end up with more friends of the same race if it is unpleasant to introduce a friend of a different race to her family.
} 
compatibility change over time.

In order to make progress, one would have to believe that it is possible to identify a group of newly chosen friends that were encountered through a process that, to a reasonable approximation, is random. ${ }^{32}$ In what follows we examine whether it is informative to follow Jackson and Rogers (2007) and Mayer and Puller (2008) who, in their models, maintain the assumption that a student encounters new friends either through her existing friends or through a process that is random. Our longitudinal data allow us to remove all friends of person $i$ at time $t$ who were identified as either being friends of $i$ at $t-1$ or friends of $i$ 's friends at $t-1$. Under the maintained assumption, we would then be left with the group of new friends who were met randomly. Observing whether the amount of sorting changes over time for this group provides information about whether beliefs change over time. ${ }^{33}$

The reality that the maintained assumption is very strong suggests that an asymmetry may exist between what can be learned from a positive and a negative finding from the data. ${ }^{34}$ If sorting decreases significantly over time when we focus on the group of new friends who are deemed by the maintained assumption to have been met randomly then it seems reasonable to conclude both that the maintained assumption has identified a useful group and that beliefs have changed over time. On the other hand, if sorting does not decrease significantly over time for this group, this could be the case because either the maintained assumption did not identify a useful group or because beliefs have not changed over time. For the 2001 cohort, the sorting results focusing only on this group are shown in the last columns of Tables 2A (best friends) and 2B (all friends). For the combined 2000 and 2001

\footnotetext{
${ }^{32}$ These new friends might, for example, be met while walking around campus, standing in line in the cafeteria, or taking part in classes or activities that are not of particular interest to any specific type or race of student.

${ }^{33}$ We find that $23.7 \%$ of friends in the middle of the first year were listed as friends at the end of the orientation period (i.e., they are not new), and that $32.1 \%$ of friends in the middle of the second year and $41.6 \%$ of friends in the middle of the third year were listed as friends in the middle of the previous year. These numbers do not vary significantly by race. We find that network effects are relatively strong in the meeting process. A new friend of a student $i$ in the middle of the first year has a .0969 probability of being a friend with any of $i$ 's friends at the end of the orientation period. A new friend of a student $i$ in the middle of the second (third) year has a $.132(.084)$ probability of being a friend with any of $i$ 's friends in the middle of the first (second) year.

${ }^{34}$ One can certainly question the assumption borrowed from Jackson and Rogers (2007) and Mayer and Puller (2008). One might also wonder whether yearly friendship observations are frequent enough to accurately identify returning friends and friends that are met through other friend. Similarly, one might wonder whether problems might arise because our question asks students to identify only four friends.
} 
cohorts, the sorting results focusing on only this group are shown in the last columns of Tables 3A (best friends) and 3B (all friends). The results in the last columns of Tables 2A, $2 \mathrm{~B}, 3 \mathrm{~A}$, and $3 \mathrm{~B}$ show substantial sorting in all periods, with the amount of sorting being very similar to that observed for the group of all students in the first columns of Tables $2 \mathrm{~A}$, 2B, 3A, and 3B. Then, it seems necessary to conclude that not much can be been learned about whether beliefs have changed from this exercise. Similar difficulties are present if one wishes to understand why being assigned a black roommate was found in Subsection 4.2 to cause a white student to have more black friends in later years.

\section{Conclusion}

We feel that it is important to be cautious about the conclusions in this paper since, among other things, it is possible that actual interracial friendship compatibility may be different at Berea than other schools. Nonetheless, this paper makes a valuable contribution by identifying a situation in which students from different races may indeed be very compatible as friends, even if very substantial amounts of racial sorting are observed. The paper raises the possibility that this may occur because students start school with mispercpetions about interracial friendship compatibility

Examining what happens over time to the overall sample suggests that, by itself, having a diverse group of students on campus will not guarantee substantial amounts of interracial friendship interaction at any stage of college. Examining what happens over time to students assigned a roommate of a different race suggests that an active policy can make a substantial difference, though. However, it is worth noting that, when the number of minority students is not large, many majority students cannot receive the treatment of being assigned a minority roommate. Further, the nature of the roommate instrument is quite unique; it is hard to think of other potential policy instruments which, in essence, force students to learn so much about each other. 


\section{Appendix —Data Construction Description}

The 2001 cohort was first asked about friendships on the baseline survey using Question A described in Section 3. We refer to the friendships that we characterize using this survey as friendships "at the time of college entrance." This cohort was asked about friendships three additional times during their first year using the same question, and we use these surveys to characterize friendships "during the first year of college." Two of these surveys (4 and 5) took place in November of the first semester while the other surveys took place during the second semester. In order to construct the friendship information for the second year, if the student responded to survey 5, we characterize friendships using information from this survey. If not, we turned to survey 4 and then, if necessary, to Survey 12 . Since $94 \%$ of our responses come from Surveys 4 or 5, friendships during the first year of college are essentially synonymous with friendships "in the middle of the first year of college." The second cohort was asked about friendships four times during their second year and four times during their third year. Using an approach similar to that described above for the first year, we use this information to construct friendships "during the second year" of college and friendships "during the third year" of college.

We observe friendship information for 335 students during the first year of college, for 275 students during the second year of college, and for 238 students during the third year of college. The numbers are less than the total sample size, 375, for three reasons. First, 14, 84, and 128 of the students in our sample had left Berea at the time of the first, second, and third year friendship surveys, respectively. Second, 21, 14, and 4 students chose not to participate in any of the friendship surveys in the first, second, and third years, respectively. Finally, 5, 2, and 5 of students who participated on the friendship surveys either indicated they had no friends or listed friends that could not be matched in the first, second, and third years, respectively. The numbers above imply that $94 \%, 95 \%$, and $98 \%$ of individuals in our sample who were still at Berea answered one or more friendship surveys for the first, second, and third years respectively. 


\section{References}

Arcidiacono, Peter, Esteban M. Aucejo, Hanming Fang, and Kenneth I Spenner. 2010. Does affirmative action lead to mismatch? A new test and evidence. Unpublished Manuscript, Duke University and University of Pennsylvania.

Ayres, Ian, and Richard Brooks. 2005. Does affirmative action reduce the number of black lawyers? Stanford Law Review 57: 1807-1854.

Boisjoly, Johanne, Greg J. Duncan, Michael Kremer, Dan M. Levy, and Jacque Eccles. 2006. Empathy or antipathy? The impact of diversity. American Economic Review 96: 1890-1905. Cornell, Brad, and Ivo Welch. 1996. Culture, information and screening discrimination. Journal of Political Economy 104: 542-571.

Jackson, Matthew, and Brian Rogers. 2007. Meeting strangers and friends of friends: How random are social networks? American Economic Review 97: 890-915.

Marmaros, David, and Bruce Sacerdote. 2006. How do friendships form? The Quarterly Journal of Economics 121: 79-119.

Mayer, Adalbert, and Steven L. Puller. 2008. The old boy (and girl) network: Social network formation on university campuses. Journal of Public Economics 92: 329-347.

Rothstein, Jesse and Albert Yoon. 2008. Mismatch in law school. Working Paper No. 14275, National Bureau of Economic Research, Cambridge, MA.

Stinebrickner, Todd, and Ralph Stinebrickner. 2003. Working during school and academic performance. Journal of Labor Economics 21: 473-491.

-. 2004. Time-use and college outcomes. Journal of Econometrics 121: 243-269.

-. 2006. What can be learned about peer effects using college roommates? Evidence from new survey data and students from disadvantaged backgrounds. Journal of Public Economics 90: 1435-1454.

-. 2008a. The effect of credit constraints on the college drop-out decision: A direct approach using a new panel study The American Economic Review 98: 2163-2184.

-. 2008b. The causal effect of studying on academic performance. The B.E. Journal of Economic Analysis and Policy (Frontiers) 8(1): Article 14. 
Table 1

DESCRIPTIVE STATISTICS - 2001 COHORT

\begin{tabular}{llll}
\hline & $\begin{array}{l}(1) \\
\text { BLACK AND } \\
\text { WHITE } \\
\mathrm{n}=354\end{array}$ & $\begin{array}{l}(2) \\
\text { WHITE } \\
\mathrm{n}=298\end{array}$ & $\begin{array}{l}\text { BLACK } \\
\mathrm{n}=56\end{array}$ \\
\hline Male & .432 & .429 & .446 \\
Black & .158 & 1.0 & 0.0 \\
High school grade point average & $3.37(.48)$ & $3.43(.462)$ & $3.09(.491)$ \\
Population density of home county & $363(535)$ & $273(436)$ & $809(728)$ \\
Family income at college entrance & $25238(18079)$ & $26535(18408)$ & $17627(15076)$ \\
Athlete in first year & .189 & .184 & .214 \\
\hline
\end{tabular}

The table shows the mean (standard deviation) for The Berea Panel Study 2001 cohort (n=375). 
Table 2A

THE PROPORTION OF STUDENTS WHO HAVE BLACK BEST FRIENDS AT THE START OF CLASSES AND IN THE MIDDLE OF YEARS ONE, TWO, AND THREE - 2001 COHORT

\begin{tabular}{|c|c|c|c|c|}
\hline & $\begin{array}{l}(1) \\
\text { ALL } \\
\text { OBSERVATIONS }\end{array}$ & $\begin{array}{l}(2) \\
\text { RESPONDENTS } \\
\text { WITH FRIENDSHIP } \\
\text { OBSERVATIONS IN } \\
\text { ALL PERIODS }\end{array}$ & $\begin{array}{l}(3) \\
\text { SAME AS } \\
\text { COLUMN } 1 \\
\text { EXCEPT } \\
\text { OMITTING } \\
\text { WHITES } \\
\text { RANDOMLY } \\
\text { ASSIGNED } \\
\text { BLACK } \\
\text { ROOMMATES }\end{array}$ & $\begin{array}{l}(4) \\
\text { SAME AS } \\
\text { COLUMN } 1 \\
\text { EXCEPT } \\
\text { OMITTING } \\
\text { RETURNING } \\
\text { FRIENDS AND } \\
\text { FRIENDS OF } \\
\text { FRIENDS }\end{array}$ \\
\hline Black (entrance) & $.696(.061) \mathrm{n}=56$ & $.757(.074) n=33$ & $.696(.061) \mathrm{n}=56$ & $.696(.061) \mathrm{n}=56$ \\
\hline Black (year 1) & $.767(.056) n=56$ & $.787(.071) \mathrm{n}=33$ & $.767(.056) \mathrm{n}=56$ & $.904(.064) n=21$ \\
\hline Black (year 2) & $.804(.058) n=46$ & $.787(.071) n=33$ & $.804(.058) n=46$ & $.782(.086) n=24$ \\
\hline Black (year 3) & $.805(.065) n=36$ & $.848(.062) n=33$ & .805 (.065) n=36 & $.846(.100) n=13$ \\
\hline White (entrance) & $.057(.013) \mathrm{n}=298$ & .068 (.019) n=175 & $.033(.010) \mathrm{n}=270$ & $.057(.013) n=298$ \\
\hline White (year 1) & $.050(.013) \mathrm{n}=279$ & $.051(.016) \mathrm{n}=175$ & .035 (.011) n=252 & .055 (.018) n=161 \\
\hline White (year 2) & $.069(.016) \mathrm{n}=229$ & $.074(.019) \mathrm{n}=175$ & $.058(.016) \mathrm{n}=204$ & $.081(.024) n=123$ \\
\hline White (year 3) & $.064(.016) \mathrm{n}=202$ & .068 (.019) n=175 & $.049(.016) \mathrm{n}=181$ & $.08(.031) \mathrm{n}=75$ \\
\hline
\end{tabular}

The entries show the proportion of students who have black best friends for various subsamples of the 2001 cohort. Numbers in parentheses are standard errors of the estimator of the population proportion.

Note 1: All friendship observations at entrance come from 2001 cohort. Column 1 uses all observations. Column 2 uses only students that answered the survey at the time of entrance, the middle of the first year, the middle of the second year, and the middle of the third year. Column 3 is the same as column one except that it omits all white students who were randomly assigned black roommates. Column 4 is the same as column one except that it omits all friends of person $i$ at a time t who can be identified as either being friends of $i$ at $t-1$ or friends of i's friends at $\mathrm{t}-1$. 
Table 2B

THE AVERAGE PROPORTION OF ALL LISTED FRIENDS WHO ARE BLACK AT THE START OF CLASSES AND IN THE MIDDLE OF YEARS ONE, TWO, AND THREE - 2001 COHORT

\begin{tabular}{|c|c|c|c|c|}
\hline & $\begin{array}{l}\text { (1) } \\
\text { ALL } \\
\text { OBSERVATIONS }\end{array}$ & $\begin{array}{l}(2) \\
\text { RESPONDENTS } \\
\text { WITH FRIENDSHIP } \\
\text { OBSERVATIONS IN } \\
\text { ALL PERIODS }\end{array}$ & $\begin{array}{l}\text { (3) } \\
\text { SAME AS } \\
\text { COLUMN } 1 \\
\text { EXCEPT } \\
\text { OMITTING } \\
\text { WHITES } \\
\text { RANDOMLY } \\
\text { ASSIGNED } \\
\text { BLACKS }\end{array}$ & $\begin{array}{l}(4) \\
\text { SAME AS } \\
\text { COLUMN } 1 \\
\text { EXCEPT } \\
\text { OMITTING } \\
\text { RETURNING } \\
\text { FRIENDS AND } \\
\text { FRIENDS OF } \\
\text { FRIENDS }\end{array}$ \\
\hline Black (entrance) & $.668(.046) \mathrm{n}=56$ & $.712(.058) n=33$ & $.668(.046) n=56$ & $.668(.045) n=56$ \\
\hline Black (year 1) & $.654(.051) n=56$ & $.686(.065) n=33$ & $.654(.051) \mathrm{n}=56$ & $.647(.057) \mathrm{n}=51$ \\
\hline Black (year 2) & $.766(.049) \mathrm{n}=46$ & $.724(.065) \mathrm{n}=33$ & $.766(.049) \mathrm{n}=46$ & $.748(.057) \mathrm{n}=46$ \\
\hline Black (year 3) & $.708(.057) \mathrm{n}=36$ & $.727(.057) n=33$ & $.708(.057) \mathrm{n}=36$ & $.784(.059) \mathrm{n}=34$ \\
\hline White (entrance) & $.097(.012) n=298$ & $.102(.016) n=175$ & $.066(.010) \mathrm{n}=270$ & $.098(.012) \mathrm{n}=298$ \\
\hline White (year 1) & $.073(.009) \mathrm{n}=279$ & $.070(.010) \mathrm{n}=175$ & $.063(.009) \mathrm{n}=252$ & $.067(.010) \mathrm{n}=261$ \\
\hline White (year 2) & $.072(.009) \mathrm{n}=229$ & $.070(.011) \mathrm{n}=175$ & $.062(.009) \mathrm{n}=204$ & $.071(.012) \mathrm{n}=212$ \\
\hline White (year 3) & $.080(.011) n=202$ & $.082(.013) \mathrm{n}=175$ & $.071(.011) \mathrm{n}=181$ & $.077(.015) \mathrm{n}=186$ \\
\hline
\end{tabular}

The entries show the average proportion of listed friends who are black for various subsamples of the 2001 cohort. For example, the upper left entry shows that the 56 black students observed in the 2001 cohort at the time of entrance have, on average, $66.8 \%$ black friends. Numbers in parentheses are standard errors of the estimator of the population mean (i.e., the mean of individual-specific proportions in the population).

Note 1: See Note 1 in Table 2A 
Table 3A

THE PROPORTION OF STUDENTS WHO HAVE BLACK BEST FRIENDS AT THE START OF CLASSES AND IN THE MIDDLE OF YEARS ONE, TWO, AND THREE - COMBINED 2000 \& 2001 COHORTS

\begin{tabular}{|c|c|c|c|c|}
\hline & $\begin{array}{l}(1) \\
\text { ALL } \\
\text { OBSERVATIONS }\end{array}$ & $\begin{array}{l}(2) \\
\text { RESPONDENTS } \\
\text { WITH FRIENDSHIP } \\
\text { OBSERVATIONS IN } \\
\text { ALL PERIODS }\end{array}$ & $\begin{array}{l}\text { (3) } \\
\text { SAME AS } \\
\text { COLUMN } 1 \\
\text { EXCEPT } \\
\text { OMITTING } \\
\text { WHITES } \\
\text { RANDOMLY } \\
\text { ASSIGNED } \\
\text { BLACKS }\end{array}$ & $\begin{array}{l}(4) \\
\text { SAME AS } \\
\text { COLUMN } 1 \\
\text { EXCEPT } \\
\text { OMITTING } \\
\text { RETURNING } \\
\text { FRIENDS AND } \\
\text { FRIENDS OF } \\
\text { FRIENDS }\end{array}$ \\
\hline Black (entrance) & $.696(.061) \mathrm{n}=56$ & N.A. (See Note 1) & $.696(.061) n=56$ & $.696(.061) n=56$ \\
\hline Black (year 1) & $.773(.039) \mathrm{n}=115$ & .785 (.049) n=70 & $.773(.039) \mathrm{n}=115$ & $.812(.043) n=80$ \\
\hline Black (year 2) & $.788(.043) \mathrm{n}=90$ & $.80(.047) n=70$ & $.788(.043) n=90$ & $.822(.056) n=45$ \\
\hline Black (year 3) & $.746(.050) n=75$ & .785 (.049) n=70 & $.746(.050) \mathrm{n}=75$ & $.75(.096) \mathrm{n}=20$ \\
\hline White (entrance) & $.057(.013) \mathrm{n}=298$ & N.A. (See Note 1) & $.033(.010) \mathrm{n}=270$ & $.057(.013) \mathrm{n}=298$ \\
\hline White (year 1) & $.052(.009) \mathrm{n}=573$ & $.052(.011) \mathrm{n}=359$ & $.037(.008) \mathrm{n}=513$ & $.054(.010) \mathrm{n}=455$ \\
\hline White (year 2) & $.066(.012) \mathrm{n}=433$ & $.064(.012) \mathrm{n}=359$ & $.051(.011) \mathrm{n}=385$ & $.078(.017) \mathrm{n}=228$ \\
\hline White (year 3) & $.058(.011) n=396$ & $.061(.012) \mathrm{n}=359$ & $.042(.010) n=352$ & $.071(.021) \mathrm{n}=140$ \\
\hline
\end{tabular}

The entries show the proportion of students who have black best friends for various subsamples of the combined 2000 \& 2001 cohorts. Numbers in parentheses are standard errors of the estimator of the population proportion.

Note 1: The information in the columns is the same as described in Note 1 of Table 2A except that, because friendship observations are not observed for the 2001 cohort at the time of entrance, Column 2 uses students that answered the survey in the middle of the first year, the middle of the second year, and the middle of the third year. 
Table 3B

THE AVERAGE PROPORTION OF ALL LISTED FRIENDS WHO ARE BLACK AT THE START OF CLASSES AND IN THE MIDDLE OF YEARS ONE, TWO, AND THREE - COMBINED 2000 \& 2001 COHORT

\begin{tabular}{|c|c|c|c|c|}
\hline & $\begin{array}{l}(1) \\
\text { ALL } \\
\text { OBSERVATIONS }\end{array}$ & $\begin{array}{l}(2) \\
\text { RESPONDENTS } \\
\text { WITH FRIENDSHIP } \\
\text { OBSERVATIONS IN } \\
\text { ALL PERIODS }\end{array}$ & $\begin{array}{l}(3) \\
\text { SAME AS } \\
\text { COLUMN } 1 \\
\text { EXCEPT } \\
\text { OMITTING } \\
\text { WHITES } \\
\text { RANDOMLY } \\
\text { ASSIGNED } \\
\text { BLACK } \\
\text { ROOMMATES }\end{array}$ & $\begin{array}{l}(4) \\
\text { SAME AS } \\
\text { COLUMN } 1 \\
\text { EXCEPT } \\
\text { OMITTING } \\
\text { RETURNING } \\
\text { FRIENDS AND } \\
\text { FRIENDS OF } \\
\text { FRIENDS }\end{array}$ \\
\hline Black (entrance) & $.668(.046) n=56$ & N.A. (See Note 1) & $.668(.046) \mathrm{n}=56$ & $.668(.045) \mathrm{n}=56$ \\
\hline Black (year 1) & $.724(.033) n=115$ & $.730(.042) n=70$ & $.654(.051) n=115$ & $.724(.034) \mathrm{n}=110$ \\
\hline Black (year 2) & $.742(.036) n=90$ & $.732(.042) n=70$ & $.766(.049) \mathrm{n}=90$ & $.728(.041) \mathrm{n}=86$ \\
\hline Black (year 3) & $.72(.038) \mathrm{n}=75$ & $.732(.039) \mathrm{n}=70$ & .708 (.057) n=75 & $.760(.059) \mathrm{n}=66$ \\
\hline White (entrance) & $.097(.012) n=298$ & N.A. (see Note 1 ) & $.066(.010) n=270$ & $.098(.012) \mathrm{n}=298$ \\
\hline White (year 1) & $.070(.006) \mathrm{n}=573$ & $.068(.007) n=359$ & $.058(.006) \mathrm{n}=513$ & $.066(.006) \mathrm{n}=555$ \\
\hline White (year 2) & $.072(.007) \mathrm{n}=433$ & $.072(.008) n=359$ & $.054(.006) n=385$ & $.079(.010) \mathrm{n}=403$ \\
\hline White (year 3) & $.070(.008) \mathrm{n}=396$ & .075 (.009) n=359 & $.058(.008) \mathrm{n}=352$ & $.062(.009) \mathrm{n}=345$ \\
\hline
\end{tabular}

The entries show the average proportion of listed friends who are black for various subsamples of the combined 2000 and 2001 cohorts. For example, an upper left entry shows that the 115 black students observed in the combined 2000 \& 2001 cohorts at the middle of the first year have, on average, $72.4 \%$ black friends.

Numbers in parentheses are standard errors of the estimator of the population mean (i.e., the mean of individualspecific proportions in the population).

Note 1: See Note 1 in Table 3A. 
Table 4

OLS REGRESSIONS

DEPENDENT VARIABLE: HSGPA OF STUDENT'S BEST FRIEND-COMBINED 2000 \& 2001 COHORTS

\begin{tabular}{lll}
\hline & $(1)$ & $(2)$ \\
& COEFFICIENT SE & COEFFICIENT SE \\
\hline Constant & $2.646(.146)$ & $2.870(.156)^{*}$ \\
HSGPA (own) & $.205(.042)^{*}$ & $.150(.044)^{*}$ \\
Black (own) & & $-.225(.058)^{*}$ \\
$\mathrm{R}^{2}$ & .034 & .056 \\
\hline
\end{tabular}

The first column shows an OLS regression of the high school grade point average (HSGPA) of a student's best friend on the student's own HSGPA. The second column adds the student's own race to the regression.

$\mathrm{n}=641$.

* Significant at $5 \%$. 
Table 5

\section{OLS REGRESSIONS \\ WHETHER BEST FRIEND IS BLACK IN MIDDLE OF THE FIRST YEAR (COLUMN 1) AND PROPORTION OF FRIENDS THAT ARE BLACK IN THE MIDDLE OF THE FIRST YEAR (COLUMN 2) - COMBINED 2000 \& 2001 COHORTS}

\begin{tabular}{lll}
\hline & $(1)$ & $(2)$ \\
\hline Black (year 1) & \multicolumn{1}{c}{ COEFFICIENT SE } & COEFFICIENT SE \\
White (year 1) & $.744^{*}(.044)$ & $.715^{*}(.036)$ \\
& $.057^{*}(.010)$ & $.071^{*}(.007)$ \\
Male-.413 & & $-.027(.017)$ \\
(Population density-325.12)/100 & $-.031(.019)$ & $-.004(.002)$ \\
Athlete in first year-.187 & $-.001(.003)$ & $-.006(.032)$ \\
(Family income -32877)/10000 & $.017(.042)$ & $.007(.005)$ \\
High school grade point average -3.389 & $-.0017(.007)$ & $-.052(.020)^{*}$ \\
$\mathrm{R}^{2}$ & $-.052(.026)^{*}$ & .694 \\
\hline
\end{tabular}

The first column uses a linear probability model (with whether a person's best friend is black as the dependent variable) to control for HSGPA and observable characteristics of the student. The second column uses an OLS regression model (with the proportion of a student's friends that are black as the dependent variable) to control for the same characteristics. So that the Black (year 1) and White (year 1) entries in the first and second columns, respectively, can be compared to the Black (year 1) and White (year 1) entries in Tables 3A and 3B, respectively, the observable characteristics are differenced from the mean sample values in the middle of the first year.

n=650 (White 540, Black 110).

* Significant at $5 \%$ 
Table 6A

THE PROPORTION OF STUDENTS WHO LIST THEIR ASSIGNED ROOMMATE FROM THE FIRST YEAR AS THEIR BEST FRIEND AT DIFFERENT POINTS IN COLLEGE

\begin{tabular}{|c|c|c|c|}
\hline & $\begin{array}{l}(1) \\
\text { MIDDLE OF } 1^{\mathrm{ST}} \\
\text { YEAR }\end{array}$ & $\begin{array}{l}(2) \\
\text { MIDDLE OF } 2^{N D} \\
\text { YEAR }\end{array}$ & $\begin{array}{l}(3) \\
\text { MIDDLE OF } \\
3^{R D} \text { YEAR }\end{array}$ \\
\hline \multicolumn{4}{|c|}{ Combined 2000 and 2001 cohorts } \\
\hline White assigned black & $.167(\mathrm{n}=60)$ & $.083(n=48)$ & $.136(n=44)$ \\
\hline White assigned white & $.165(\mathrm{n}=321)$ & $.058(n=240)$ & $.042(n=214)$ \\
\hline Black assigned white & $.180(n=61)$ & $.062(n=48)$ & $.073(n=41)$ \\
\hline \multicolumn{4}{|l|}{2001 Cohort } \\
\hline White assigned black & $.185(n=27)$ & $.08(n=25)$ & $.142(n=21)$ \\
\hline White assigned white & $.187(\mathrm{n}=155)$ & $.062(\mathrm{n}=127)$ & $.055(n=108)$ \\
\hline Black assigned white & $.179(n=28)$ & $.086(n=23)$ & $.111(n=18)$ \\
\hline
\end{tabular}


Table 6B

THE PROPORTION OF STUDENTS WHO LIST THEIR ASSIGNED ROOMMATE FROM THE FIRST YEAR AS ONE OF THEIR FOUR BEST FRIENDS AT DIFFERENT POINTS IN COLLEGE

(1)

MIDDLE OF $1^{\text {ST }}$

YEAR

Combined 2000 and 2001 cohorts

White assigned black

White assigned white

Black assigned white

2001 Cohort

White assigned black

White assigned white

Black assigned white

$.444(n=27)$

$.354(\mathrm{n}=155)$

$.393(\mathrm{n}=28)$
(2) MIDDLE OF $2^{\mathrm{ND}}$ YEAR

$\begin{array}{lll}.35(\mathrm{n}=60) & .229(\mathrm{n}=48) & .159(\mathrm{n}=44) \\ .367(\mathrm{n}=321) & .133(\mathrm{n}=240) & .088(\mathrm{n}=214) \\ .344(\mathrm{n}=61) & .167(\mathrm{n}=48) & .146(\mathrm{n}=41)\end{array}$

$.24(n=25)$

$.142(\mathrm{n}=21)$

$.118(\mathrm{n}=127)$

$.083(\mathrm{n}=108)$
(3)

MIDDLE OF $3^{\mathrm{RD}}$ YEAR

$.174(\mathrm{n}=23) \quad .111(\mathrm{n}=18)$


Table 7

OLS REGRESSIONS

WHETHER ROOMMATE NAMED AS A FRIEND IN MIDDLE OF FIRST YEAR WHITE STUDENTS RANDOMLY ASSIGNED ROOMMATES, COMBINED 2000 \& 2001 COHORTS

\begin{tabular}{lll}
\hline & $(1)$ & $(2)$ \\
& COEFFICIENT SE & COEFFICIENT SE \\
\hline Constant & $.434(.039)^{*}$ & $.433(.040)^{*}$ \\
MISMATCH & $-.155(.063)^{*}$ & $-.156(.64)^{*}$ \\
Roommate black & & $.006(.067)$ \\
$\mathrm{R}^{2}$ & .015 & .056 \\
\hline
\end{tabular}

MISMATCH is absolute value of difference between the HSGPA of a student and the HSGPA of his roommate. $\mathrm{n}=380$. 
Table 8A

THE AVERAGE PROPORTION OF FRIENDS WHO ARE BLACK FOR STUDENTS RANDOMLY ASSIGNED ROOMMATES - COMBINED 2000 \& 2001 COHORTS

\begin{tabular}{|c|c|c|c|}
\hline & $\begin{array}{l}(1) \\
\text { MIDDLE OF } 1^{\mathrm{ST}} \\
\text { YEAR }\end{array}$ & $\begin{array}{l}(2) \\
\text { MIDDLE OF } 2^{\text {ND }} \\
\text { YEAR }\end{array}$ & $\begin{array}{l}(3) \\
\text { MIDDLE OF } \\
\text { YEAR }\end{array}$ \\
\hline \multicolumn{4}{|l|}{$\begin{array}{l}\text { Including roommate assigned in } \\
\text { first year }\end{array}$} \\
\hline White assigned black & $.165(.026) \mathrm{n}=60$ & $.213(.036) \mathrm{n}=48$ & $.166(.036) \mathrm{n}=44$ \\
\hline White assigned white & $.060(.007) \mathrm{n}=321$ & $.053(.008) \mathrm{n}=240$ & $.059(.010) \mathrm{n}=214$ \\
\hline $\begin{array}{l}\mathrm{t} \text { test statistic. Null: average } \\
\text { proportion does not vary by race of } \\
\text { roommate }\end{array}$ & -4.863 & -6.546 & -3.705 \\
\hline \multicolumn{4}{|l|}{$\begin{array}{l}\text { Not including roommate assigned } \\
\text { in first year }\end{array}$} \\
\hline White assigned black & $.081(.021) \mathrm{n}=60$ & $.159(.035) \mathrm{n}=48$ & $.136(.036) \mathrm{n}=44$ \\
\hline White assigned white & $.067(.008) \mathrm{n}=321$ & $.054(.008) \mathrm{n}=240$ & $.059(.010) \mathrm{n}=214$ \\
\hline $\begin{array}{l}\mathrm{t} \text { test statistic. Null: average } \\
\text { proportion does not vary by race of } \\
\text { roommate }\end{array}$ & -.656 & -4.341 & -2.661 \\
\hline
\end{tabular}

Note: The test involves a difference in population means. The population mean is the average proportion in the population. 
Table 8B

THE AVERAGE PROPORTION OF FRIENDS WHO ARE BLACK FOR STUDENTS

RANDOMLY ASSIGNED ROOMMATES - STUDENTS WITH FRIENDSHIP OBSERVATIONS IN ALL THREE YEARS, COMBINED 2000 \& 2001 COHORTS

\begin{tabular}{|c|c|c|c|}
\hline & $\begin{array}{l}(1) \\
\text { MIDDLE OF } 1^{\mathrm{ST}} \\
\text { YEAR }\end{array}$ & $\begin{array}{l}(2) \\
\text { MIDDLE OF } 2^{\mathrm{ND}} \\
\text { YEAR }\end{array}$ & $\begin{array}{l}(3) \\
\text { MIDDLE OF } 3^{\mathrm{RD}} \\
\text { YEAR }\end{array}$ \\
\hline \multicolumn{4}{|l|}{$\begin{array}{l}\text { Including roommate assigned in } \\
\text { first year }\end{array}$} \\
\hline White assigned black & $.166(.032) \mathrm{n}=41$ & $.207(.040) \mathrm{n}=41$ & $.172(.038) \mathrm{n}=41$ \\
\hline White assigned white & $.056(.008) \mathrm{n}=197$ & $.054(.009) \mathrm{n}=197$ & $.062(.011) \mathrm{n}=197$ \\
\hline $\begin{array}{l}\mathrm{t} \text { test statistic. Null: average } \\
\text { proportion does not vary by race of } \\
\text { roommate }\end{array}$ & -4.496 & -5.645 & -3.587 \\
\hline \multicolumn{4}{|l|}{$\begin{array}{l}\text { Not including roommate assigned } \\
\text { in first year }\end{array}$} \\
\hline White assigned black & $.085(.021) \mathrm{n}=41$ & $.166(.039) \mathrm{n}=41$ & $.146(.038) \mathrm{n}=41$ \\
\hline White assigned white & $.063(.008) \mathrm{n}=197$ & $.054(.009) \mathrm{n}=197$ & $.062(.011) \mathrm{n}=197$ \\
\hline $\begin{array}{l}\mathrm{t} \text { test statistic. Null: average } \\
\text { proportion does not vary by race of } \\
\text { roommate }\end{array}$ & -.851 & -4.177 & -2.733 \\
\hline
\end{tabular}

Note: The test involves a difference in population means. The population mean is the average proportion in the population. 